\title{
Expiration Date Error
}

National Cancer Institute

\section{Source}

National Cancer Institute. Expiration Date Error. NCI Thesaurus. Code C62999.

Problem associated with errors in identification of expiration date. 